\title{
Enacting the \\ Bible in medieval and early modern drama
}

EDITED BY

EVA VON CONTZEN AND

CHANITA GOODBLATT

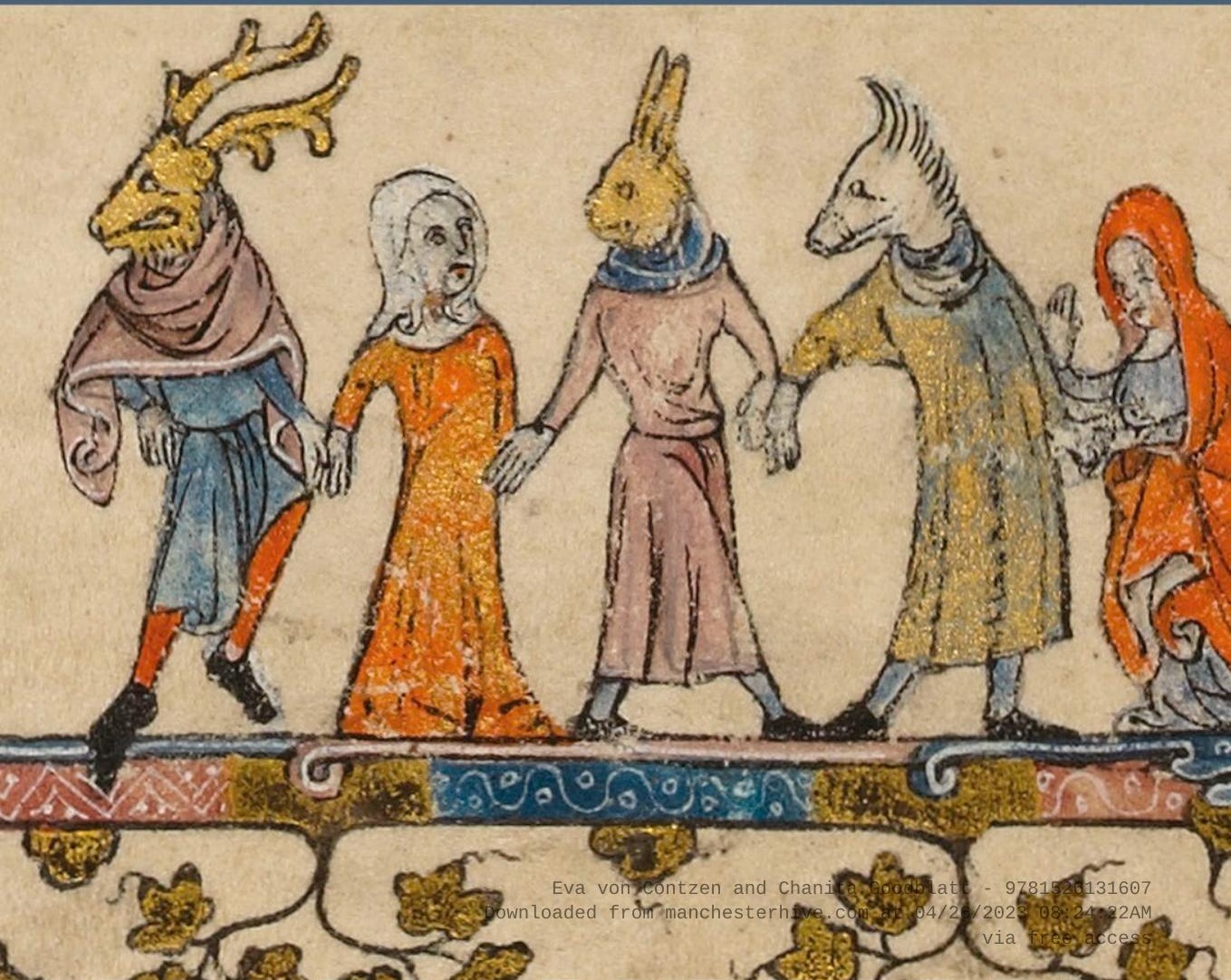




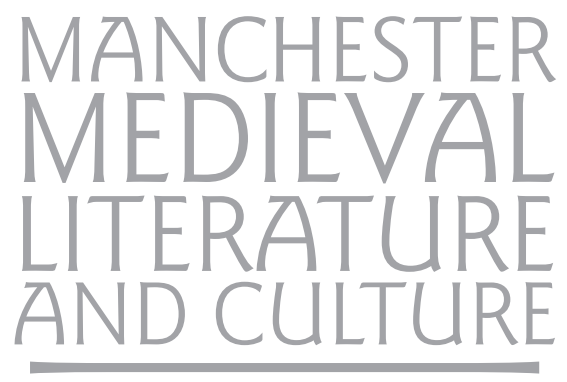

ENACTING THE BIBLE IN MEDIEVAL AND EARLY MODERN DRAMA

\section{MANCHESTER} 1824

Manchester University Press 
Series editors: Anke Bernau, David Matthews and James Paz

Series founded by: J. J. Anderson and Gail Ashton

Advisory board: Ruth Evans, Patricia C. Ingham, Andrew James Johnston, Chris Jones, Catherine Karkov, Nicola McDonald, Sarah Salih, Larry

MANCHESTER MEDIEVAL LITERATURE AND CULTURE Scanlon and Stephanie Trigg

Manchester Medieval Literature and Culture publishes monographs and essay collections comprising new research informed by current critical methodologies on the literary cultures of the Middle Ages. We are interested in all periods, from the early Middle Ages through to the late, and we include post-medieval engagements with and representations of the medieval period (or 'medievalism'). 'Literature' is taken in a broad sense, to include the many different medieval genres: imaginative, historical, political, scientific, religious. While we welcome contributions on the diverse cultures of medieval Britain and are happy to receive submissions on Anglo-Norman, Anglo-Latin and Celtic writings, we are also open to work on the Middle Ages in Europe more widely, and beyond.

\section{Titles available in the series}

16. Nonhuman voices in Anglo-Saxon literature and material culture James Paz

17. The church as sacred space in Middle English literature and culture Laura Varnam

18. Aspects of knowledge: Preserving and reinventing traditions of learning in the Middle Ages Marilina Cesario and Hugh Magennis (eds)

19. Visions and ruins: Cultural memory and the untimely Middle Ages Joshua Davies

20. Participatory reading in late-medieval England Heather Blatt

21. Affective medievalism: Love, abjection and discontent Thomas A. Prendergast and Stephanie Trigg

22. Performing women: Gender, self, and representation in late-medieval Metz Susannah Crowder

23. The politics of Middle English parables: Fiction, theology, and social practice Mary Raschko

24. Contemporary Chaucer across the centuries

Helen M. Hickey, Anne McKendry and Melissa Raine (eds)

25. Borrowed objects and the art of poetry: Spolia in Old English verse Denis Ferhatović

26. Rebel angels: Space and sovereignty in Anglo-Saxon England jill Fitzgerald

27. A landscape of words: Ireland, Britain and the poetics of space, 700-1250 Amy Mulligan

28. Household knowledges in late-medieval England and France

Glenn D. Burger and Rory G. Critten (eds)

29. Practising shame: Female honour in later medieval England Mary C. Flannery

30. Dating Beowulf: Studies in intimacy

Daniel C. Remein and Erica Weaver (eds)

31. Enacting the Bible in medieval and early modern drama Eva von Contzen and Chanita Goodblatt (eds) 


\section{Enacting the Bible in medieval and early modern drama}

EDITED BY EVA VON CONTZEN AND

CHANITA GOODBLATT

Manchester University Press 
While copyright in the volume as a whole is vested in Manchester University Press, copyright in individual chapters belongs to their respective authors, and no chapter may be reproduced wholly or in part without the express permission in writing of both author and publisher.

An electronic version of chapter 9 is also available under a Creative Commons (CC-BY-NC-ND) licence, thanks to the support of the Swiss National Science Foundation, which permits non-commercial use, distribution and reproduction provided the editor(s), chapter author and Manchester University Press are fully cited and no modifications or adaptations are made. Details of the licence can be viewed at https://creativecommons.org/licenses/by-nc-nd/4.0/

Published by Manchester University Press

Altrincham Street, Manchester M1 7JA

www.manchesteruniversitypress.co.uk

British Library Cataloguing-in-Publication Data

A catalogue record for this book is available from the British Library

ISBN 9781526131591 hardback

First published 2020

The publisher has no responsibility for the persistence or accuracy of URLs for any external or third-party internet websites referred to in this book, and does not guarantee that any content on such websites is, or will remain, accurate or appropriate.

Front cover-

Bodleian Library MS. Bodl. 264, fol. 21v, photo Bodleian Libraries

Typeset

by Toppan Best-set Premedia Limited 